\title{
Using a market basket to explore regional food systems
}

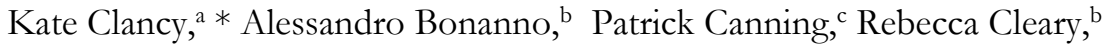 \\ Zach Conrad, ${ }^{\mathrm{d}}$ David Fleisher, ${ }^{\mathrm{e}}$ Miguel Gómez, ${ }^{\mathrm{f}}$ Timothy Griffin, ${ }^{\mathrm{d}}$ \\ Ryan Lee, ${ }^{\mathrm{g}}$ Daniel Kane, ${ }^{\mathrm{h}}$ Anne Palmer, ${ }^{\mathrm{g}}$ Kristen Park, ${ }^{\mathrm{f}}$ Christian J. Peters, ${ }^{\mathrm{d}}$ \\ and Nicole Tichenor ${ }^{\mathrm{i}}$
}

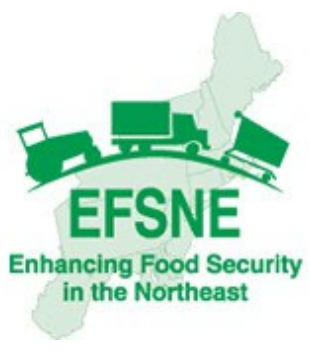

Submitted May 9, 2017 / Revised August 2 and September 13, 2017 / Accepted September 14, 2017 / Published online December 20, 2017

Citation: Clancy, K., Bonanno, A., Canning, P., Cleary, R., Conrad, Z., Fleisher, D., Gomez, M., Griffin, T., Lee, R., Kane, D., Palmer, A., Park, K., Peters, C., \& Tichenor, N. (2017). Using a market basket to explore regional food systems. Journal of Agriculture, Food Systems, and Community Development, 7(4), 163-178.

http://dx.doi.org/10.5304/jafscd.2017.074.018

Copyright (C) 2017 by New Leaf Associates, Inc.

\begin{abstract}
The market basket chosen for the Enhancing Food Security in the Northeast (EFSNE) project was one of its major tools, as its contents served as the subject of a variety of analyses across the research teams. The interdisciplinary systems project studied multiple components of food systems in the
\end{abstract}

a * Corresponding author: Kate Clancy, Food systems consultant; University Park, MD 20782 USA; klclancy@,comcast.net

b Department of Agricultural and Resource Economics, Colorado State University; Clark Building, Room B327; Fort Collins, CO 80524 USA; alessandro.bonanno@,colostate.edu and rcleary@,colostate.edu

c USDA-Economic Research Service; 1400 Independence Ave., SW, Mail Stop 1800; Washington, DC 20250-1800 USA; pcanning@ers.usda.gov

d Friedman School of Nutrition Science and Policy, Tufts University; 150 Harrison Avenue; Boston MA 02111 USA; zach.Conrad@tufts.edu, timothy.griffin@tufts.edu, and Christian.Peters@tufts.edu

e USDA-Agricultural Research Service-Northeast Area, Adaptive Cropping Systems Laboratory; 10300 Baltimore Avenue; Beltsville, MD 20750 USA;

david.fleisher@ars.usda.gov
Northeast region. One of the team members' first collaborative exercises was the choice of the eight items representing the major food groups, including different processed forms of food and healthier versions of several. This article summarizes the information gathered on the market basket items,

f Dyson School of Applied Economics and Management, Cornell University; 340D Warren Hall; Ithaca, NY 14853 USA; mig7@,cornell.edu and ksp3@,cornell.edu

g Center for a Livable Future, Johns Hopkins Bloomberg School of Public Health; 615 North Wolfe Street, W7010; Baltimore, MD 21205-2179 USA; rlee89@jhu.edu and apalmer6@jhu.edu

h School of Forestry and Environmental Studies, Yale University; 370 Prospect Street; New Haven, CT 06511 USA; daniel.kane@yale.edu

i Sustainability Institute, University of New Hampshire; 131 Main Street; Durham NH 03824 USA; nicole.tichenor@unh.edu

\section{Disclosure}

The research was supported by the U.S. Department of Agriculture National Institute of Food and Agriculture (USDA NIFA) Agriculture and Food Research Initiative (AFRI) grant \#2011-68004-30057: Enhancing Food Security in the Northeast through Regional Foods Systems (EFSNE). 
including (1) some salient data describing the state of each food item's industry; (2) the current regional-self-reliance production level; (3) consumer purchases of these items in the Northeast utilizing secondary data sources and data gathered in project intercept surveys; (4) store inventories, including prices and where the food is produced or manufactured; (5) the percentage of the market basket food that is produced regionally, as well as the regional economic value-added percentage; (6) models of six of the foods predicting the effect on production and supply chains of changes in the system, such as increased demand and environmental changes; and (7) foodprints for each food. Market baskets are frequently used instruments in food environment and cost studies. Using market baskets in EFSNE allowed the teams to aggregate and interconnect data from multiple analyses done by researchers from multiple disciplines to tell a rich story about a specific set of foods, their supply chains, and the future opportunities to enhance their production and distribution in the region.

\section{Keywords}

Regional Food Systems; Regional Self-Reliance; Food Security; Market Basket; Supply Chains; Marketing and Distribution Systems; Economic Impact; Consumer Purchasing Behavior; Optimization Models; Adaptation to Climate Change

\section{Introduction}

The EFSNE project was supported by a grant from the U.S. Department of Agriculture (USDA) 2010 Agricultural and Food Research Initiative (AFRI) Global Food Security program area. The priority at the time was the development of projects on local and regional food systems that would increase food security in disadvantaged U.S. communities and create viable local/regional economies. The grants in this new program would be larger and longer in duration to encourage greater collaboration among institutions and organizations, to undertake both basic and applied research, and to engage the communities in the projects' work. To that end, projects were required, among other things, to include a multistate, multi-institutional, and transdisciplinary team composed of public and private for-profit and nonprofit sectors, and to be focused on urban and/or rural self-defined geographic regions centered on regional food systems that included low-income communities. Projects would be integrated in that they contained research, education, and extension components.

The introduction (Peters, Clancy, Hinrichs, \& Goetz, 2017) provides an overview of the EFSNE project in general, which is a unique interdisciplinary, multi-institutional, complex systems project addressing many different components of food security in the Northeast, and more specifically, the socioeconomic and biophysical constraints to regional food system expansion. The program's long-term goal is to assess whether greater reliance on regionally produced food can improve food access for low-income communities as well as benefit farmers, actors in the food supply chain, and others in the food system. Our primary objective is to increase our understanding of the mechanisms necessary to more broadly enhance food security via mainstream markets in a region, with special emphasis on low-income communities as requested by the USDA AFRI initiative.

The market basket that we chose was one of the center points of the project, as its contents served as the subject of multiple analyses across the research teams. The most important reason we developed the basket was to have a collaboration vehicle to organize the work of the teams around the same foods. We wanted to build a rich description of a select number of foods to deepen our knowledge of some of the variables that compose supply chains and production capacity. Over time, we also wanted to keep the different teams apprised of each other's work on the same foods. It would have been disjointed and frustrating to have teams or individual researchers studying different foods - and would have made it impossible to prepare all of the systems and cross-project papers that are some of the most important outputs of the project. The market basket was an important tool, but only one of several that were necessary to define the project as we envisioned. This paper reports on the components of the project that dealt with the individual foods in the market basket and is the only place where those pieces are organized to tell a cohesive story. The majority of the findings from the project across all the 
teams is found in research already published or in preparation, many of which are in this article's reference list. This paper is a review of how the food items were chosen, how the research teams applied their analyses to each food, and the joint results of the research findings for each market basket food.

Market baskets are frequently used instruments in food environment and cost studies, and are defined as "a list of foods [often many items long] that represent an adequate total diet, which may include both the healthy and unhealthy foods frequently consumed by the population" (McKinnon, Reedy, Morrissette, Lytle, \& Yaroch, 2009, p. S125). In EFSNE the basket assumed a larger role and a smaller size.

Several of the project's objectives were served by utilizing a market basket: we wanted to know (1) what regional production looks like at the present time and the capacity for producing more of these particular foods in the future; (2) which regionally produced foods are now found in stores in lowincome areas; (3) what the supply chains look like for these foods to identify where the leverage points might be along the chain to increase the amounts going into supermarkets in low-income areas; and (4) who the purchasers are and what the purchasing patterns of these foods are in the stores we studied.

\section{Methods}

For findings from seven separate research analyses presented here there was a suite of methods utilized from across a variety of disciplines, including nutrition, soil science, rural sociology, agricultural economics, community development, and others. The first section of this article describes the market basket selection. The second section briefly describes the methods used in the analyses. For ease of reporting and comprehension, the methods and the results of the models developed across the project are presented at the end of the results section.

\section{Market Basket Selection}

One of the first collaborative exercises of the research teams was choosing the basket's eight items (Table 1). We considered a number of criteria as we selected the items:
- Whether the Northeast region was a major producer of the food: Fresh apples, cabbage, potatoes, and fluid milk met this criterion. Fresh potatoes offered an interesting debate among the nutritionists and others; some argued against their inclusion because the Special Supplemental Nutrition Program for Women, Infants, and Children (WIC) was in the process of removing them from their list of approved foods. Not all the team's nutritionists agreed, and in the end the decision was made to include them because the only vegetable under consideration for the climate change scenarios being conducted by several of the researchers was potatoes (see models, p. 174). We chose ground beef because it is the number-one selling form of beef, and although beef production is not a major part of Northeast agriculture, dairy is, and a significant portion of ground beef comes from the dairy sector.

- As a complement to the previous criterion, we also wanted to determine which of the foods were more likely to be produced in the Northeast or outside the region.

- Whether the food was a staple component of most diets in the low-income areas in which we worked: All except one food, bread, met this criterion. We discussed several possible grain products, including rice and tortillas, but our optimal choice was bread (whole grain and white) because it is purchased and consumed by a large percentage of the population (Agriculture and Agri-Food Canada, 2012). Although

\section{Table 1. EFSNE Market Basket Items}

\begin{tabular}{ll}
\hline - Apples & Bread \\
- Cabbage & o white \\
- Potatoes & o whole wheat \\
- Frozen broccoli & - Milk \\
o in sauce & ○ whole \\
o without sauce & o low-fat \\
- Canned peaches & - Ground beef \\
o in syrup & ○ regular \\
o in juice & o lean \\
\hline
\end{tabular}


bread wheat is produced in small amounts in the Northeast, a good deal of the bread in retail markets is manufactured in the region. Furthermore, the whole-grain bread approved for WIC users is labeled as such on the shelves of stores, making it easy to identify.

- Whether the food existed in recommended or less recommended forms (healthier and less healthy): Along with the three fresh vegetables, this is the case for all of the foods.

- How many food items could reasonably be studied by the teams: We chose eight foods.

- Because we were looking at multiple crop and animal products in the Northeast, we wanted the basket to contain foods from all the basic food groups in order to gain knowledge about where the Northeast food system stands with regard to at least one member of each group.

- A mix of fresh and processed foods, including frozen and canned, as processing is the optimal way to maintain markets and provide regional products year-round.

We included frozen broccoli not because any of the frozen broccoli sold in the U.S. is produced in the country, but because broccoli for freezing and fresh use was produced in many states in the Northeast in past decades, and a project studying the feasibility of returning broccoli production to the Eastern seaboard was underway (Atallah, Gómez, \& Björkman, 2014).

Finally, because there were four vegetable products in the basket we wanted to have at least two fruits. We looked at data on fruit production in the Northeast and chose peaches, which are produced in several states in the region. Nationally, canned peaches are consumed in higher amounts than are fresh peaches (USDA Economic Research Service [USDA-ERS], 2016a).

\section{Research Methods}

The data presented here on specific market basket items were gathered by researchers from different disciplines serving on three different teams (production, distribution, and consumption), and at different times over the period of 2011 to 2015. Each team included researchers from a mix of disciplines. Figure 1 is a summary of methods utilized by the teams.

Members of the Production team (PROD) used multiple data sets to produce measures of regional self-reliance (RSR) from 2001 to 2009. RSR is the net balance between production of a given commodity and the regional availability of the food or food group (Griffin, Conrad, Peters, Ridberg, \& Tyler, 2014). Agricultural land use was estimated using USDA, National Agricultural Statistics Service (USDA-NASS) surveys, the NASS agricultural censuses, and individual state departments of agriculture annual and specialty crop reports (Griffin et al., 2014). Land area and production data were available for 130 foods. The USDA-ERS Food Availability Data System was used as a proxy for estimates of food consumption at the regional level. A total of 89 foods were utilized in the RSR calculation, because consumption data were not available for 41 foods and thus they were excluded from the analysis.

Another team member calculated the annual, per-capita cropland footprint of six of the foods, using the same structure as the U.S. Foodprint model (Peters, Picardy, Darrouzet-Nardi, Wilkins, Griffin, \& Fick, 2016). Through three sets of calculations, the model estimates the agricultural land area required per capita to grow the foods in a complete diet and, correspondingly, the carrying capacity of the land base of the conterminous U.S. The first calculation estimated the annual, per capita food needs of the population; the second estimated the individual land area required for each agricultural commodity in the diet; and the third estimated the potential carrying capacity of U.S. agricultural land. In the Northeast model, changes were made to input parameters on crop yields, land availability, and livestock feed requirements to reflect conditions in the region. The original biophysical simulation model estimated land use requirements for complete diets, but the data reported here are for the individual market basket foods.

The Distribution team (DIST) conducted case studies of 11 stores in our low-income locations between 2011 and 2015. The locations are 
Baltimore, MD; Charleston, WV; East Harlem, NY; Essex County, VT; Kent County, DE;

Madison County, NY; Onondaga County, NY; Pittsburgh, PA; and Syracuse, NY. Each case included a supply-chain analysis of two of the market basket foods, focusing on product flow and volume, prices, marketing margins, and share of retail price among supply chain members (Park, Gómez, \& Clancy, 2017). An industry profile for each food was prepared to accompany the supplychain analyses utilizing 18 USDA and industry data sources. All of the sources are cited in the text and in the reference list.

Members of the Consumption (CONS) team analyzed data from two waves of intercept surveys conducted with 1,997 shoppers exiting EFSNEparticipating stores between 2013 and 2015. The data collected included information on shopping habits, the respondents' purchases of marketbasket items in the previous month, demographic characteristics, and respondents' participation in national nutrition programs such as the Supplemental Nutrition Assistance Program (SNAP) or the Women, Infants, and Children program (WIC). For the intercept surveys, the results refer to tests of difference in means (with different variances across subsamples).

At the same time as the intercept surveys,

\section{Figure 1. Overview of Data Sources and Methods Used}

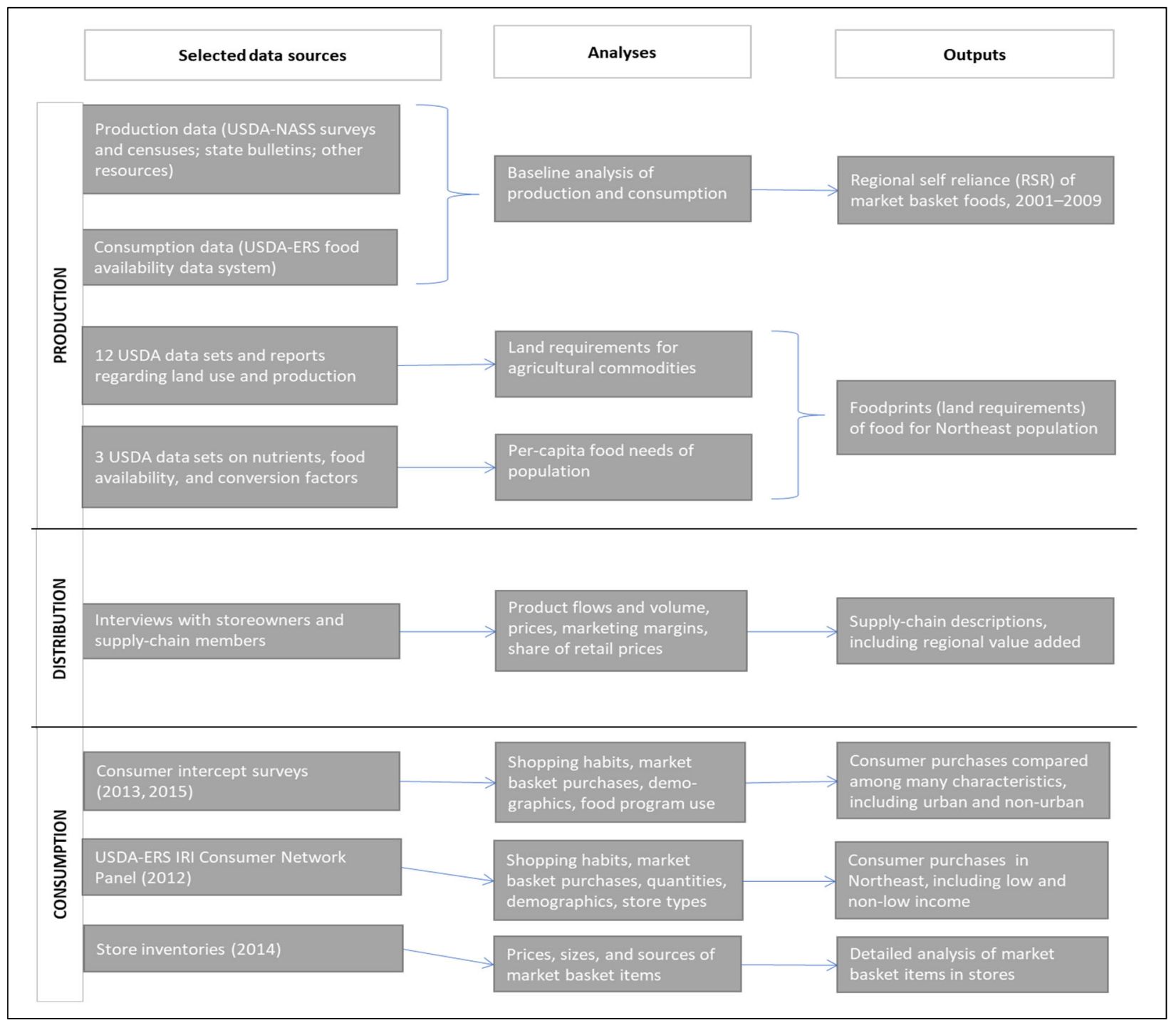


CONS conducted store inventories three times over the course of the project to gather data on food prices, amounts, and sources of different versions of the market basket items. Due to space limitations all the data reported here are from the third inventory, conducted in 2014.

Team members also analyzed secondary household purchase data from the IRI Consumer Network PanelTM, courtesy of the USDA-ERS. The data come from a sample of households who record all their product purchases by means of in- home scanner devices. Roughly 120,000

households annually participate in the data collection program. Of these, about $50 \%$ show enough purchases to be included in the static panel of households, which is used for analyses (Muth et al., 2016). The researchers scrutinized multiple elements related to the purchase of market basket items at the national $(n=62,503)$ and Northeast regional level $(n=12,770)$ by lowincome (at or below $200 \%$ of the poverty level)/non-low-income, and urban/rural status

Table 2. Overview of Regional Production, Distribution, and Availability of Market Basket Items

\begin{tabular}{|c|c|c|c|c|c|}
\hline $\begin{array}{l}\text { Market } \\
\text { basket item }\end{array}$ & $\begin{array}{c}\text { Regional } \\
\text { self-reliance } \\
\text { (RSR) } \\
\end{array}$ & $\begin{array}{c}\text { Foodprint } \\
\text { (cropland acres) }\end{array}$ & Unit & Type & $\begin{array}{l}\text { Proportion of stores } \\
\text { stocking the specific } \\
\text { food sourced from } \\
\text { regional distributors }\end{array}$ \\
\hline & & & & Red delicious & $43 \%$ \\
\hline \multirow[t]{2}{*}{ Apples } & \multirow[t]{2}{*}{$81 \%$} & \multirow[t]{2}{*}{$1.59 \times 10^{-3}$} & \multirow[t]{2}{*}{$3 \mathrm{lb}$. bag } & Golden delicious & $38 \%$ \\
\hline & & & & Mclntosh & $80 \%$ \\
\hline Cabbage & $105 \%$ & $0.25 \times 10^{-3}$ & $1 \mathrm{lb}$. & & not available \\
\hline \multirow{3}{*}{ Potatoes } & \multirow{3}{*}{$38 \%$} & \multirow{3}{*}{$1.62 \times 10^{-3}$} & \multirow{3}{*}{$5 \mathrm{lb}$. bag } & Red potatoes & $17 \%$ \\
\hline & & & & White round & $64 \%$ \\
\hline & & & & Russet potatoes & $20 \%$ \\
\hline \multirow{4}{*}{$\begin{array}{l}\text { Broccoli } \\
\text { (frozen) }\end{array}$} & \multirow{4}{*}{$1 \%$} & \multirow{4}{*}{$0.64 \times 10^{-3}$} & \multirow{4}{*}{1 package } & Without sauce (name brand) & $0 \%$ \\
\hline & & & & Without sauce (generic) & $0 \%$ \\
\hline & & & & With sauce (name brand) & $0 \%$ \\
\hline & & & & With sauce (generic) & $0 \%$ \\
\hline \multirow{4}{*}{$\begin{array}{l}\text { Peaches } \\
\text { (canned) }\end{array}$} & \multirow{4}{*}{$\begin{array}{l}26 \% \text { (both fresh } \\
\text { and processed) }\end{array}$} & \multirow{4}{*}{$1.03 \times 10^{-3}$} & \multirow{4}{*}{ Can } & In juice (name brand) & \multirow{4}{*}{$33 \%$} \\
\hline & & & & In juice (generic) & \\
\hline & & & & In syrup (name brand) & \\
\hline & & & & In syrup (generic) & \\
\hline \multirow{4}{*}{ Bread } & \multirow{4}{*}{$\begin{array}{l}8 \% \text { (for all food } \\
\text { grains) }\end{array}$} & \multirow{4}{*}{ not able to calculate } & \multirow{4}{*}{1 loaf } & White bread 1 & $70 \%$ \\
\hline & & & & White bread 2 & $70 \%$ \\
\hline & & & & Wheat bread 1 & $70 \%$ \\
\hline & & & & Wheat bread 2 & $70 \%$ \\
\hline \multirow{3}{*}{ Dairy } & \multirow{3}{*}{$\begin{array}{l}76 \% \text { (fluid milk } \\
\text { equivalent) }\end{array}$} & \multirow{3}{*}{$\begin{array}{c}16.39 \times 10^{-3} \\
\text { (includes culled cattle) }\end{array}$} & \multirow{3}{*}{1 gallon } & Whole milk & $71 \%$ \\
\hline & & & & $2 \%$ milk & $71 \%$ \\
\hline & & & & $1 \%$ milk & $73 \%$ \\
\hline \multirow{3}{*}{ Beef } & \multirow{3}{*}{$16 \%$ (all beef) } & \multirow{3}{*}{ not able to calculate } & \multirow{3}{*}{$1 \mathrm{lb}$. ground } & $75 \% / 25 \%$ lean/fat & \multirow{3}{*}{$0 \% *$} \\
\hline & & & & $80 \% / 20 \%$ lean/fat & \\
\hline & & & & $85 \% / 15 \%$ lean/fat & \\
\hline
\end{tabular}

*There was a small amount of regional beef in one of the stores.

Note: $1 \mathrm{lb} .=045 \mathrm{~kg} ; 1$ gallon= 3.79 liters 
using the USDA 2013 Rural-Urban Continuum Codes (Cleary, Bonanno, \& Cho, 2017). They calculated the percentage of consumers who purchased six of the eight market basket items over one year (2012), as well as average expenditures and average quantities purchased per household member and the purchases across different types of stores. For the results, they performed tests for the difference in means accounting for sample weights.

\section{Results}

In this section, we first offer profiles of the market basket foods, incorporating findings from seven analyses. Each begins with a quick overview of salient industry facts and continues with results of the PROD, DIST, and CONS research. We report on specific market basket foods found in two different stores throughout the results section. The second part of the results section presents the methods and results from the modeling exercises.

Table 3. Supply Chain Analysis of Market Basket Items

\begin{tabular}{|c|c|c|c|c|c|c|c|c|c|c|}
\hline \multirow{2}{*}{$\begin{array}{l}\text { Market } \\
\text { basket } \\
\text { item }\end{array}$} & \multirow[b]{2}{*}{ Store } & \multirow{2}{*}{$\begin{array}{l}\% \text { in stores } \\
\text { produced } \\
\text { in region }\end{array}$} & \multirow{2}{*}{$\begin{array}{c}\text { Regional } \\
\text { economic } \\
\text { value } \\
\text { added after } \\
\text { production }\end{array}$} & \multicolumn{7}{|c|}{ Retail price allocation } \\
\hline & & & & $\begin{array}{l}\text { Farmer/ } \\
\text { producer }\end{array}$ & $\begin{array}{c}\text { Processor/ } \\
\text { packer }\end{array}$ & $\begin{array}{l}\text { Transpor- } \\
\text { tation }\end{array}$ & $\begin{array}{l}\text { Produce } \\
\text { wholesaler }\end{array}$ & $\begin{array}{c}\text { Grocery } \\
\text { wholesaler }\end{array}$ & Other & Retailer \\
\hline \multirow{2}{*}{ Apples } & Store 1 & $78 \%$ & $42 \%$ & $48 \% *$ & & $1 \%$ & \multicolumn{2}{|c|}{$4 \%$} & $2 \%$ (broker) & $44 \%$ \\
\hline & Store 2 & $77 \%$ & $68 \%$ & $33 \% *$ & & $11 \%$ & \multicolumn{2}{|c|}{$10 \%$} & & $44 \%$ \\
\hline \multirow{5}{*}{ Cabbage } & \multirow{3}{*}{ Store 1} & $36 \%$ & $44 \%$ & & & & & & & \\
\hline & & \multicolumn{2}{|c|}{$\begin{array}{l}\text { Supply chain origin } \\
\text { Northeast }\end{array}$} & $20 \%$ & & $2 \%$ & $5 \%$ & $6 \%$ & & $67 \%$ \\
\hline & & \multicolumn{2}{|c|}{$\begin{array}{l}\text { Supply chain origin } \\
\text { Florida }\end{array}$} & $18 \%$ & & $8 \%$ & $1 \%$ & $6 \%$ & & $67 \%$ \\
\hline & \multirow[b]{2}{*}{ Store 2} & $2 \%$ & $40 \%$ & & & & & & & \\
\hline & & \multicolumn{2}{|c|}{$\begin{array}{l}\text { One of the store's six } \\
\text { supply chains }\end{array}$} & $32 \% \sim$ & & $8 \%$ & \multicolumn{2}{|c|}{$19 \%$} & & $41 \%$ \\
\hline \multirow{4}{*}{ Potatoes } & & $64 \%$ & $55 \%$ & & & & & & & \\
\hline & Store 1 & \multicolumn{2}{|c|}{ Northeast supplier } & $37 \% *$ & & $2 \%$ & \multicolumn{2}{|c|}{$30 \%$} & & $31 \%$ \\
\hline & & \multicolumn{2}{|c|}{ Western shipper } & $45 \%^{\wedge}$ & & $22 \%$ & \multicolumn{2}{|c|}{$1 \%$} & 1\% (broker) & $31 \%$ \\
\hline & Store 2 & $20 \%$ & $44 \%$ & $26 \% * *$ & & $7 \%$ & $8 \%$ & & & $47 \%$ \\
\hline \multirow{3}{*}{$\begin{array}{l}\text { Broccoli } \\
\text { (frozen) }\end{array}$} & & $0 \%$ & $67 \%$ & & & & & & & \\
\hline & Store 1 & \multicolumn{2}{|c|}{$\begin{array}{l}\text { Supply chain origin } \\
\text { Guatemala }\end{array}$} & $24 \% * *$ & $22 \%$ & $11 \%$ & $13 \%$ & & & $31 \%$ \\
\hline & Store 2 & $0 \%$ & $41 \%$ & $44 \%$ & $4 \%$ & $15 \%$ & & & & $37 \%$ \\
\hline \multirow{2}{*}{$\begin{array}{l}\text { Peaches } \\
\text { (canned) }\end{array}$} & Store 1 & $0 \%$ & $50 \%$ & $10 \%$ & $40 \%$ & & $22 \%$ & & & $28 \%$ \\
\hline & Store 2 & $0 \%$ & $33 \%$ & $13 \%$ & $55 \%$ & & $6 \%$ & & & $26 \%$ \\
\hline Bread & Store 1 & $0 \%$ & Unknown & & & & & & $\begin{array}{l}68 \% \text { (manu- } \\
\text { facturer) }\end{array}$ & $32 \%^{\wedge}$ \\
\hline \multirow{4}{*}{ Milk } & Store 1 & $100 \%$ & $100 \%$ & $45 \%$ & $41 \%$ & & & & & $14 \%$ \\
\hline & \multirow{3}{*}{ Store 2} & $100 \%$ & $100 \%$ & & & & & & & \\
\hline & & \multicolumn{2}{|c|}{ Supply chain one } & $54 \%$ & $42 \%$ & & & & & $4 \%$ \\
\hline & & \multicolumn{2}{|c|}{ Supply chain two } & $56 \%$ & $38 \%$ & & & & & $4 \%$ \\
\hline \multirow{2}{*}{$\begin{array}{l}\text { Beef } \\
\text { (ground) }\end{array}$} & Store 1 & $0 \%$ & $29 \%$ & & $47 \%$ & $4 \%$ & & $13 \%$ & & $36 \%$ \\
\hline & Store 2 & $0 \%$ & $38 \%$ & & $39 \%$ & $3 \%$ & & $17 \%$ & & $41 \%$ \\
\hline
\end{tabular}

* grower shipper; ^ only shipper; producer-packer-shipper; ** grower processor; ^^ ${ }^{\wedge}$ wholesaler/retailer 
Individual Food Profiles

Apples. Data from USDA show that in 2015 the Northeast region produced about $12 \%$ of the country's fresh apples and 35\% of the processing crop measured by net value (USDA NASS, 2017). New York (2nd) and Pennsylvania (4th) are two of the top five apple-producing states, at 1,350 million pounds (612 million kilograms) and 515 million pounds (233 million $\mathrm{kg}$ ), respectively (USDA NASS, 2016e). Table 2 presents the RSRs and foodprints for each item.

In the store inventories, we recorded the sources of production and distribution if that information was available; we could not discern the production source of apples. Table 2 does show the proportion of the apples sourced from regional distributors. The proportion was calculated from information received from the store inventories and storeowner interviews. Table 3 contains information about the supply-chain analyses for each food and store. For apples the regional supply chain provides $78 \%$ of the stores' supply. It also shows the retail price allocation across one each of the regional (store one) and national (store two) supply chains.

Table 4 presents selected findings from the analysis of data gathered from intercept surveys.

Cabbage. Although cabbage consumption is declining (USDA ERS, 2015), it is still the fourthhighest value vegetable crop grown in the Northeast region (USDA NASS, 2017). New York and California rotate from year to year as the country's leading producers, with the former producing $20 \%$ of the U.S. crop in 2015 (USDA NASS, 2016b). The supply-chain analyses showed that $36 \%$ and $2 \%$ of the cabbage sold in stores one and two, respectively, were grown in the Northeast; the latter store is in Pittsburgh, on the far west end of the region. Other interesting data about cabbage are shown in Tables 2, 4, and 5.

Potatoes. Data produced by USDA show that in 2015 the Northeast region produced about 6\% of the country's fresh and processed potato crops as measured by value and by weight (USDA NASS, 2016f, 2017). The largest producer in the region is Maine, with $64 \%$ of the crop, followed by New

Table 4. Intercept Survey Respondents' Characteristics with Respect to Purchasing Market Basket Items

\begin{tabular}{|c|c|c|c|c|c|c|c|c|c|c|c|c|}
\hline \multirow[b]{2}{*}{$\begin{array}{l}\text { Market basket } \\
\text { item }\end{array}$} & \multirow[b]{2}{*}{ Type } & \multirow{2}{*}{$\begin{array}{c}\text { Purchased } \\
\text { last month } \\
\\
\text { Yes }\end{array}$} & \multicolumn{2}{|c|}{ Female } & \multicolumn{2}{|c|}{$\begin{array}{c}\text { Average number of } \\
\text { children under } 5\end{array}$} & \multicolumn{2}{|c|}{$\begin{array}{c}\text { Average years of } \\
\text { education }\end{array}$} & \multicolumn{2}{|c|}{$\begin{array}{c}\text { Program } \\
\text { participation }\end{array}$} & \multicolumn{2}{|c|}{ Of all purchasers } \\
\hline & & & 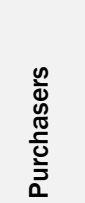 & 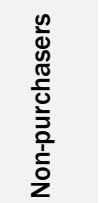 & 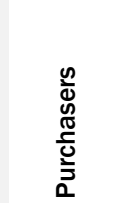 & 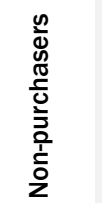 & 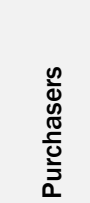 & 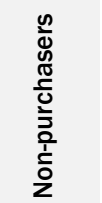 & 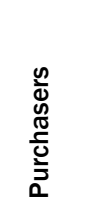 & 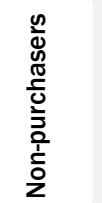 & 营 & 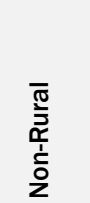 \\
\hline Apples & & $52 \%$ & $68 \%$ & $64 \%$ & 0.42 & $0.30 *$ & 13.2 & 13.2 & $45 \%$ & $42 \%$ & $53 \%$ & $52 \%$ \\
\hline Cabbage & & $42 \%$ & $69 \%$ & $63 \% *$ & 0.38 & 0.35 & 12.9 & $13.5^{*}$ & $49 \%$ & $40 \% *$ & $37 \%$ & $44 \%$ \\
\hline Potatoes & & $67 \%$ & $67 \%$ & $64 \%$ & 0.4 & $0.29 *$ & 13 & $13.7 *$ & $47 \%$ & $37 \% *$ & $65 \%$ & $68 \%$ \\
\hline $\begin{array}{l}\text { Frozen } \\
\text { broccoli }\end{array}$ & & $43 \%$ & $70 \%$ & $63 \% *$ & 0.42 & $0.31 *$ & 12.8 & $13.6 *$ & $49 \%$ & $39 \% *$ & $42 \%$ & $43 \%$ \\
\hline $\begin{array}{l}\text { Canned } \\
\text { peaches }\end{array}$ & & $25 \%$ & $67 \%$ & $66 \%$ & 0.47 & $0.33 *$ & 12.2 & $13.6 *$ & $55 \%$ & $40 \% *$ & $24 \%$ & $25 \%$ \\
\hline \multirow{2}{*}{ Bread } & White & $41 \%$ & $66 \%$ & $67 \%$ & 0.43 & $0.32 *$ & 12.5 & $13.7 *$ & $54 \%$ & $36 \% *$ & $40 \%$ & $41 \%$ \\
\hline & Wheat & $45 \%$ & $69 \%$ & $64 \%$ & 0.38 & 0.35 & 13.4 & $13.1^{*}$ & $43 \%$ & $44 \%$ & $49 \%$ & $43 \%$ \\
\hline \multirow[b]{2}{*}{ Milk } & Whole & $29 \%$ & $63 \%$ & $67 \%$ & 0.44 & $0.33 *$ & 12.6 & $13.5^{*}$ & $55 \%$ & $39 \% *$ & $25 \%$ & $30 \%$ \\
\hline & $\begin{array}{l}\text { Fat free, } \\
1 \%, \text { or } 2 \%\end{array}$ & $44 \%$ & $67 \%$ & $65 \%$ & 0.41 & 0.32 & 13.3 & 13.2 & $44 \%$ & $43 \%$ & $50 \%$ & $43 \%$ \\
\hline \multirow{2}{*}{ Ground beef } & $\begin{array}{l}\begin{array}{l}\text { Regular } \\
\text { (fat }>15 \% \text { ) }\end{array} \\
\end{array}$ & $25 \%$ & $63 \%$ & $67 \%$ & 0.41 & 0.35 & 12.4 & $13.5 *$ & $56 \%$ & $39 \% *$ & $15 \%$ & $28 \%$ * \\
\hline & $\begin{array}{l}\text { Lean } \\
\text { (fat } \leq 15 \%)\end{array}$ & $26 \%$ & $70 \%$ & $65 \%$ & 0.44 & 0.34 & 12.9 & $13.4 *$ & $50 \%$ & $41 \% *$ & $28 \%$ & $26 \%$ \\
\hline
\end{tabular}

* Statistically different at the $1 \%$ significance level 
York and then five other states (USDA NASS, 2016f, 2017). We could not determine the production locations of the three varieties of potatoes we inventoried, but distributors are identified on the labels so we can report the proportion of stores stocking the product from the region in Table 2. In Table 3 there are examples of the retail price allocations across various supply chains for several of the round white potato suppliers from different areas of the U.S. The substantial differences in transportation costs and wholesale shares are evident in the calculations.

Cleary et al. (2017), using the IRI data, calculated the percentage of consumers who purchased potatoes over one year (2012), the price per pound, and the percentage purchased in supercenters versus grocery stores (Table 5). Interestingly, nonurban households were less likely to make their purchases in grocery stores; they utilize superstores more frequently for all their food shopping (Cleary et al., 2017).

Frozen broccoli. While approximately $80 \%$ of the fresh broccoli supply in the U.S. in 2015 was produced domestically, $92 \%$ of the frozen broccoli consumed (farm weight) was imported, accounting for $30 \%$ of all frozen vegetable imports (USDA ERS, 2015). The imports come primarily from Mexico, Guatemala, and Ecuador (USDA ERS, 2017). Frozen broccoli consumption in the U.S. is a bit less than half of fresh consumption. The percapita availability of frozen broccoli in 2014 was 2.6 pounds $(1.2 \mathrm{~kg})$ farm weight, 1.9 pounds (0.9 $\mathrm{kg}$ ) trimmed product (USDA ERS, 2015).

In the store case studies, no broccoli sold in a frozen form was produced in the U.S., but Table 3 shows the percent of the regional economic valueadded activities. We also show the allocation of retail prices across one of the international supply chains for a frozen broccoli product- the one presented in Table 3 originated in Guatemala.

From the secondary data analysis (Table 5), we see that the average price per pound in that year was significantly higher for non-low-income households, and significantly lower in non-urban locations. In the EFSNE intercept surveys, $43 \%$ had purchased frozen broccoli in the last month

Table 5. Purchasing Patterns of Market Basket Items in the Northeast IRI Consumer Network Panel Sample, by Income and Rural/Urban Status

\begin{tabular}{|c|c|c|c|c|c|c|c|c|c|c|c|c|c|c|c|c|c|}
\hline \multirow[b]{2}{*}{$\begin{array}{l}\text { Market } \\
\text { basket } \\
\text { item }\end{array}$} & \multirow[b]{2}{*}{ Type } & \multicolumn{4}{|c|}{$\begin{array}{l}\text { Percentage of Households } \\
\text { Purchasing in } 2012(\%)\end{array}$} & \multicolumn{4}{|c|}{ Price Paid Per Unit (US\$) } & \multicolumn{4}{|c|}{$\begin{array}{l}\text { Percentage Purchased in } \\
\text { Supercenters (\%) }\end{array}$} & \multicolumn{4}{|c|}{$\begin{array}{l}\text { Percentage Purchased in } \\
\text { Grocery Stores (\%) }\end{array}$} \\
\hline & & 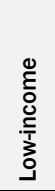 & 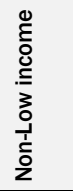 & 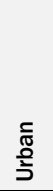 & 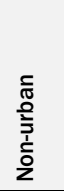 & 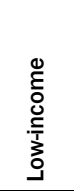 & 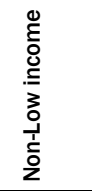 & $\begin{array}{l}\frac{c}{0} \\
\frac{0}{2} \\
\text { 文 }\end{array}$ & 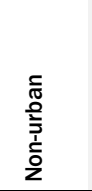 & 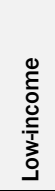 & 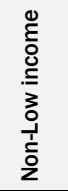 & $\begin{array}{l}\frac{1}{\pi} \\
\text { 율 } \\
\text { ग }\end{array}$ & 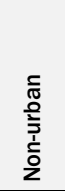 & 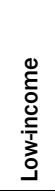 & 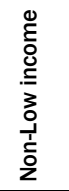 & 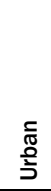 & 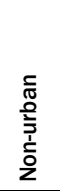 \\
\hline \multicolumn{2}{|l|}{ Potatoes } & 61 & 63 & 62 & $72 *$ & 0.63 & $0.72 *$ & 0.70 & 0.65 & 10 & $7 *$ & 7 & $18 *$ & 77 & 80 & 80 & $76 *$ \\
\hline \multicolumn{2}{|l|}{$\begin{array}{l}\text { Frozen } \\
\text { broccoli }\end{array}$} & 36 & $40 *$ & 39 & 38 & 1.69 & $1.82 *$ & 1.79 & $1.68 *$ & 12 & $7 *$ & 7 & $23 *$ & 77 & 80 & 80 & $72 *$ \\
\hline \multicolumn{2}{|l|}{$\begin{array}{l}\text { Canned } \\
\text { peaches }\end{array}$} & 31 & 29 & 29 & $39 *$ & 1.63 & $1.73 *$ & 1.71 & 1.65 & 15 & $10 *$ & 9 & $25 *$ & 67 & $75 *$ & 74 & $62 *$ \\
\hline \multirow{2}{*}{ Bread } & White & 62 & $55 *$ & 55 & $71^{*}$ & 1.35 & $1.53 *$ & 1.48 & 1.43 & 10 & $7 *$ & 6 & $20 *$ & 74 & $81 *$ & 80 & $70 *$ \\
\hline & Wheat & 50 & 51 & 51 & 50 & 1.75 & $1.93 *$ & 1.89 & 1.81 & 10 & $7 *$ & 7 & $20 *$ & 72 & 73 & 74 & $67 *$ \\
\hline \multirow[b]{2}{*}{ Milk } & Whole & 49 & $42 *$ & 44 & 44 & 4.45 & $4.84 *$ & 4.77 & $4.29 *$ & 10 & $6 *$ & 6 & $18 *$ & 68 & $74 *$ & 73 & $67 *$ \\
\hline & $\begin{array}{l}1 \% \text {, or } 2 \%, \\
\text { or fat free }\end{array}$ & 76 & $82 *$ & 80 & 82 & 4.18 & $4.40 *$ & 4.40 & $3.80 *$ & 10 & $7 *$ & 6 & $20 *$ & 70 & 73 & 73 & $68 *$ \\
\hline \multirow{2}{*}{$\begin{array}{l}\text { Ground } \\
\text { beef }\end{array}$} & $\begin{array}{l}\text { Regular } \\
\text { (fat >15\%) }\end{array}$ & 14 & $9 *$ & 9 & $20 *$ & 2.85 & $3.02 *$ & 2.95 & 3.00 & 52 & 46 & 43 & $71 *$ & 30 & 33 & 35 & $20 *$ \\
\hline & $\begin{array}{l}\text { Lean } \\
\text { (fat } \leq 15 \%)\end{array}$ & 6 & $8 *$ & 7 & $10 *$ & 4.69 & 4.93 & 4.92 & $4.59 *$ & 56 & $41 *$ & 41 & $69 *$ & 25 & 32 & 32 & 23 \\
\hline
\end{tabular}

Source: Cleary, Bonanno, \& Cho, 2017.

* indicates a statistical difference between the means of each pair of groups (low-income vs. non low-income and urban vs. non-urban) at at least the $1 \%$ level. 
(see Table 4).

Canned peaches. Peaches are the most popular canned fruit in the U.S. as measured by percapita consumption (USDA ERS, 2016b). In 2015, $97 \%$ of those peaches were grown and processed in California (USDA NASS, 2016e). The fruit is grown in the Northeast for fresh use $(2.3 \%$ of the U.S. total), and also for processing (another $5 \%$ by volume) (USDA NASS, 2017). None of the canned peaches sold in the stores originated in the Northeast, but the distributors of canned peaches to four of the stores were located in the region.

Bread. While wheat was once produced in the Northeast in abundant quantities (Northern Grain Growers Association, n.d.), it is highly unlikely that bread produced for the mass market in the region is made from Northeast wheat at this time. Although some wheat is grown in 42 of the 50 states, none of the top 10 state producers is in the Northeast (USDA NASS, 2016b). The RSR (percent of regional consumption met by regional production, divided by 100) for all food grains is about $8 \%$ percent, but it is not possible to calculate a separate value for wheat. There is little public information collected or available about the bread industry; we assume that the bread sold in the project stores is not made with flour grown in the region.

Bread baking, wholesaling, and retailing are different from wheat production in that the supplychain case studies and discussions with store owners suggest that a significant amount of bread is baked in the region. In the store inventories (where we examined two each of white and whole-wheat loaves of different brands because so many breads were available) we can determine that across stores about $70 \%$ of the breads were manufactured and distributed in the region.

In the secondary data analysis of respondents from the Northeast, about $50 \%$ of the sample households had purchased wheat bread. Significant differences in variables are found with regard to white bread prices and purchasing. See Table 4 for characteristics of bread purchasers from the intercept surveys.

Milk. In 2015 all the states in the Northeast region had operating dairy farms, with two of them, New York (4) and Pennsylvania (5), in the top five producing states (USDA NASS, 2016d).
Dairy-farm operators located in the Northeast have about $15 \%$ of all milk cows in the U.S. and account for about $15 \%$ of total U.S. production by pounds (30.4 million or 13.8 million $\mathrm{kg}$ ) and value (US $\$ 5.5$ billion) (USDA NASS, 2016d).

In the store inventories, we recorded information about whole, $2 \%$, and $1 \%$ milk. The Northeast was the source of about $70 \%$ of each type of milk. The allocations of the retail price across the supply chains are shown in Table 3.

Table 5 contains information from the secondary analysis of households from the Northeast. Low-fat milk $(0 \%, 1 \%$, and $2 \%)$ was purchased by about $80 \%$ of respondents, while the intercept survey data show that $44 \%$ purchased low-fat milk in the last month; see Table 4.

Ground beef. Ground beef is the most consumed form of beef in the U.S., representing 63\% of total food service beef volume and $37 \%$ of beef revenue, and representing $49 \%$ of retail beef volume and $39 \%$ of beef revenue (Speer, Brink, \& McCully, 2015). Although the Northeast is not a major beef-cattle producing region, two of the states (New York and Pennsylvania) are in the top five milk-producing states in the country (see milk description above). A decade ago, an analysis was published reporting that about $25 \%$ of dairy cattle are removed from production every year (Lowe $\&$ Gereffi, 2009) because of lowered performance or productivity following 4 to 6 years of production. Most of the meat from culled dairy cows is processed into ground beef for fast food or supermarket retail (Lowe \& Gereffi, 2009). In 2014 about $20 \%$ of the total number of culled cows in the U.S. (USDA NASS, 2016c) entered the ground beef supply chain from the Northeast.

The RSR calculation for all beef in the Northeast is $16 \%$. The value-added through the wholesaler and retailer for ground beef was 38\% in one store and $29 \%$ in the other.

In the secondary data analysis of households in the Northeast region (Table 5), the percentage purchasing regular ground beef varied by income and urban/non-urban locations. There was a significant difference in the type of store in which non-urban households purchased ground beef; they purchased much more frequently from superstores. Table 5 shows the purchases by different groups. 


\section{Models}

For many decades, agricultural scientists have utilized modeling to explore multiple facets of agricultural systems for many different purposes. These purposes include predicting the future production of crops, arriving at a better understanding of environmental effects, simulating the effects of shocks to the system, such as increased demand or climate change, and many other objectives (Jones et al., 2017). EFSNE researchers developed models that explore scenarios for six of the market basket foods. Table 6 presents a summary of these models. They offer critical information as to the leverage points for increasing production capacity and food security in the region, and so are presented here in some detail.

Distribution team members utilized a disaggregated price-equilibrium model to answer the question of which approach to reducing carbon dioxide emissions would be the best strategy for the apple industry to pursue (Alkhannan, Lee, Gómez, \& Gao, 2017). Using different simulations they applied their model to the U.S. apple supply chain, studying production in six states, including New York and Pennsylvania, accounting for $90 \%$ of the production in the U.S. Carbon dioxide emissions were used as a measure of environmental impact; apple production quantities and producer and retail prices were some measures of economic impact. The researchers considered three different strategies: (1) a carbon tax to penalize emissions; (2) a land-sparing mechanism in which apple production yields increase and the spared land sequesters carbon; and (3) investments in new storage technologies that emit less carbon dioxide. They concluded that improved storage technologies seem to have the potential to reduce emissions to a greater extent than land-sparing efforts. Moreover, when they combined several strategies they found that a carbon tax along with storage innovations demonstrated even more potential to reduce emissions, and provided the lowest increase in apple prices per pound for consumers.

Another output from the Distribution team is a model that estimates the supply chain impacts of demand for cabbage, increased enough to close the current gap between actual and recommended consumption of dark leafy greens for low- and middleincome populations (Yeh, Nishi, \& Gómez, 2017).

Table 6. Overview of Models Used to Explore Six Market Basket Items in Northeast Region

\begin{tabular}{|c|c|c|c|c|}
\hline EFSNE team & $\begin{array}{l}\text { Market basket } \\
\text { item }\end{array}$ & Model type & Simulated scenarios & Simulated outcomes \\
\hline Distribution & Apples & $\begin{array}{l}\text { Spatially and temporally } \\
\text { disaggregated price } \\
\text { equilibrium }\end{array}$ & $\begin{array}{l}\text { Ways to reduce } \mathrm{CO}_{2} \text { emissions } \\
\text { (carbon tax, land-sparing } \\
\text { mechanisms, investments in } \\
\text { new storage technologies) }\end{array}$ & $\begin{array}{l}\text { Best choices to reduce } \\
\text { emissions }\end{array}$ \\
\hline Distribution & Cabbage & $\begin{array}{l}\text { Spatially-disaggregated- } \\
\text { intertemporal } \\
\text { transshipment }\end{array}$ & $\begin{array}{l}\text { Increased demand for fresh } \\
\text { cabbage }\end{array}$ & $\begin{array}{l}\text { Production potential, supply } \\
\text { chain and retailer costs, optimal } \\
\text { regions and seasons for } \\
\text { increased production }\end{array}$ \\
\hline Distribution & Broccoli & $\begin{array}{l}\text { Production- } \\
\text { transportation } \\
\text { optimization } \\
\end{array}$ & $\begin{array}{l}\text { Increased regionalization of } \\
\text { fresh supply chains }\end{array}$ & $\begin{array}{l}\text { Supply chain and consumer } \\
\text { costs, food miles }\end{array}$ \\
\hline Distribution & Milk & $\begin{array}{l}\text { Spatially disaggregated } \\
\text { transshipment }\end{array}$ & $\begin{array}{l}\text { Increased localization of } \\
\text { supply chains }\end{array}$ & $\begin{array}{l}\text { Food miles, GHG emissions, } \\
\text { employment, economic activity }\end{array}$ \\
\hline \multirow{2}{*}{ Production } & \multirow{2}{*}{ Potatoes } & \multirow{2}{*}{ Geo-spatial crop } & $\begin{array}{l}\text { Increased land use for potato } \\
\text { production }\end{array}$ & \multirow{2}{*}{$\begin{array}{l}\text { Production potential and } \\
\text { adaptations }\end{array}$} \\
\hline & & & $\begin{array}{l}\text { Projected regional impacts of } \\
\text { climate change }\end{array}$ & \\
\hline Production & Winter wheat & Geo-spatial crop & $\begin{array}{l}\text { Projected regional impacts of } \\
\text { climate change }\end{array}$ & $\begin{array}{l}\text { Production potential and } \\
\text { adaptations }\end{array}$ \\
\hline
\end{tabular}


Specifically, the researchers asked what would happen if the number of acres devoted to cabbage for the fresh market and coleslaw could increase, and where such an increase could occur. The study included all regions in the U.S. and seasonal differences in both production and consumption. Under a scenario of a $10 \%$ increase in demand, total domestic production increases 247 million pounds (112 million kg), and supply-chain costs increase about $13 \%$. However, wholesale prices increase by $38 \%$ relative to the baseline, an increase that could incentivize growers to increase production until demand is met, but would mean higher cost for consumers during the transition. In the second simulation, the researchers determined the optimal regions and seasons that could increase production to avoid the high increases in cost. According to the model, New York in the fall season is the optimal supply location/season for acreage expansion. The total supply-chain costs decrease in this model, and retail prices increase only minimally. About half the additional demand for cabbage in the Northeast is likely to be met within the region in this scenario, and New York could supply cabbage to other regions in the fall. Arizona and northern Florida were the optimal locations for spring production.

Distribution team members used a production and transportation model to determine the cost of increased regionalization of fresh broccoli, asking how supply chain costs and consumer prices change when production is reallocated across space and seasons (Atallah et al., 2014). The researchers used the broccoli-producing regions on the Eastern Seaboard as their focus, which include five Southern states not in the Northeast region. Put simply, the findings are that increasing broccoli acreages in the East increases annual supply chain costs by $1 \%$, while production costs increase by less than $1 \%$ because lower transportation costs offset the increase in production costs. The reduction in transportation costs is responsible for a decrease in the marginal cost of broccoli in some eastern locations.

It is clear from the RSR and other measures that milk is a strongly regionalized commodity in the Northeast; it is shipped across the states in the region. An exercise to model the effects of localizing the dairy supply chain (that is, to constrain shipment and purchase of milk to a geographic boundary such as a state) examined fuel use, economic, and job effects. The research demonstrated that localization would lead to longer distances traveled by fluid milk and other dairy products, and an increase in greenhouse gas emissions. Furthermore, gains in employment and economic activity would be modest, increasing by only a few jobs and a small percentage of the economic activity of the Northeast dairy industry per month (Nicholson, He, Gómez, Gao, \& Hill, 2015).

Members of the production team used a geospatial crop-modeling tool to compare current production with potential production of potatoes in the Northeast under different land use and climate scenarios (Mutiibwa, Fleisher, Resop, \& Timlin, 2017; Resop, Fleisher, Timlin, Mutiibwa, \& Reddy, 2016). The first phase of the study concluded that a large amount of land is potentially available for potato production-but less is available if limitations are taken into account, such as rocky soils, the question of substitution for other crops, climate conditions, and water availability. In one scenario, the researchers calculated that if each county in the region added an additional 123 acres (50 hectares) of land for potato production, there was the potential to produce $41 \%$ more potatoes. The same team also assessed the impacts of midcentury (2050-2080) climate change on potatoes. The results indicated that potatoes were highly sensitive to projected increases in temperature, with reductions in yield ranging between $30 \%$ and $70 \%$ from historical values if adaptation measures such as adjusting planting dates were not taken. Simple measures like this could reduce the negative impact by roughly half the projections.

Using the same methodology as employed in the potato study, a model for winter wheat was used by the Production team to assess potential production capacity and climate change responses in the region (Mutiibwa et al., 2017). Among other things, the study indicated that there was a higher potential for increasing grain yields in Maine. Midcentury (2050-2080) predicted climate impacts on winter wheat production were positive in all states: 
an average yield increase of about $1.7 \mathrm{Mg}$ per hectare, or an increase of $50 \%$ with respect to historical data, was simulated. This result was primarily due to projected increases in air temperatures, and suggests the region may have the capacity to generate more of its own wheat supply in the future.

\section{Discussion}

In the EFSNE project we have examined a number of components of food security for the entire region, as well as the community food security of lower-income areas in the region. Among other methods, we have illuminated these components through the use of a market basket of eight foods. By examining the same foods through the lenses of multiple disciplines we have built a rich picture of each. In this section we describe our findings in the aggregate and identify some of the knowledge gaps that should be filled in order to proceed with activities and interventions to enhance the region's long-term food security.

One of the obvious ways to expand production volume and variety is to expand the geographic area from which food is sourced in a sustainable way (Ruhf \& Clancy, 2010). Our objectives of determining which of the market basket foods are produced in the region, as well as which are found in the stores in low-income areas, have been met through several analyses. There is a broad spectrum of RSR proportions (see Table 2) verifying that some foods are more inherently regional (apples, cabbage, milk, and potatoes) than others (bread, beef, frozen broccoli, and canned peaches). We found that $100 \%$ of the milk, over $75 \%$ of the apples, almost $50 \%$ of the potatoes in the two stores, and about $35 \%$ of the cabbage in one of the stores were produced in the Northeast. Yet we also demonstrate that the economic value added at the regional level from the activities of downstream supply-chain members is impactful, and it extends to the other market basket foods, ranging from $76 \%$ for frozen broccoli and $50 \%$ for canned peaches to $38 \%$ for ground beef. More research is needed on a variety of foods to identify those that could be produced and distributed in larger amounts in the region, as well as the necessary resources and policies.

Two-thirds of intercept survey respondents responded that they had purchased potatoes in the last month, $52 \%$ had purchased apples, and $43 \%$ had purchased frozen broccoli, and thus the criterion of the market basket of items being purchased by shoppers in low-income areas was met. A higher share of respondents purchased low-fat milk compared to whole (44\% versus $29 \%$ ) in the last month; a slightly higher share had purchased more wholewheat bread (44\%) than white (40\%); and about the same share had purchased ground beef (regular fat $[25 \%]$ and lean [26\%]). One of the market basket items was purchased with a lower frequency: about one-fourth of respondents had purchased canned peaches. Female respondents and those with more children under five years of age were purchasers of the most market basket items. Nutrition program participant purchasers of market basket items tended to have more children under five years of age and have fewer years of education.

In the secondary data analysis of households in the Northeast region (Cleary et al., 2017), we corroborate the findings above by demonstrating that a higher share of low-income than non-lowincome households bought more market basket items. This is likely due to the fact that this particular data set includes only information regarding food at home as does the intercept survey data, and non-low-income households eat out more (U.S. Bureau of Labor Statistics, 2014). For all market items except lean beef, low-income households paid a lower average price. This is a welcome finding, even though we cannot say that the foods are affordable for all households.

These purchasing analyses help us to better understand urban and rural food security issues and are being integrated with other findings to uncover more connections. For example, our third objective was to identify leverage points in supply chains for increasing the amounts of these foods entering supermarkets in low-income areas. In many of the supply-chain cases we looked at (and in other research, for example King et al., 2010), wholesalers wield a lot of control over what products are available to retailers, especially those supplying the large chains of smaller supermarkets, such as the Save-A-Lot supermarkets (Park, Gómez, \& Clancy, 2017). More analysis is needed to discern how the procurement, sales, and profits 
of these distributors can be served while supporting regional entities.

Finally, retailers play a critical role in expanding markets for regionally produced and processed foods. We saw that owners and managers of stores participating in the project who have more autonomy than national chain stores are searching out both local and regionally produced products for their stores. This is an added burden, but one they are willing to undertake to meet their customers' requests (Park et al., 2017). Supply chains that value regionally produced food will be able to make this easier for supermarket owners.

By definition, a region will have a larger land base than a local area to utilize in meeting food needs. But that land base has to be kept for, and in, production (Ruhf \& Clancy, 2010). In this vein, the models are a useful starting point for more research that examines how to increase production capacity in the future. They offer optimistic scenarios of apple supply chains that limit carbon dioxide emissions, increased cabbage production in the fall season in New York, potato grower adaptations to climate change, greatly increased production on small additional acreages across Northeast counties, significantly increased broccoli production in the Northeast at minimal cost to producers and consumers, a good potential to increase winter wheat production in the region, and the benefits of maintaining the milk supply chain as a regional construct.

All the scenarios above are within the realm of possibility, although all have limitations. It could be profitable to increase potato production to the level it was prior to 2002, before the loss of a great deal of land used to grow potato in the Northeast, given the issues of increasing temperatures and scarcer water supplies in some parts of the country. If growers decide to adopt new varieties and grow more broccoli in the region, a larger portion of Northeast demand could be met and some might be frozen as well. There are several efforts underway to increase the production of organic wheat suitable for bread-making (Podhaizer, 2008). Although these efforts may not meet the volume demand of the region's bakers for production of bread for the mass market, this research is a useful contribution to self-reliance.

\section{Conclusions}

Although the EFSNE project worked with a small market basket, we believe that the information from this research points to a number of useful lessons. First, we found it instructive to study the entire supply chain. It has not been a common practice in food supply-chain studies to feature the value added by all parts of the chain, but instead to focus more on returns to producers. As previously discussed, this value added to the region from downstream chain members is significant for many products.

We also suggest moderating the oft-delivered message to consumers that fresh foods are more important in diets than other forms, because continuing consumption of non-fresh foods could benefit all supply-chain actors. Frozen and canned foods are critical season-extenders, especially of foods grown in the higher latitudes of the Northeast (and other similar regions). In addition, lowerincome households that have less access to fresh foods could benefit nutritionally from purchasing processed foods. Processed foods also provide more income to regional producers and decrease transportation costs.

There is still much research needed to fill in gaps and better understand how parts of the systems that meet food security needs in the Northeast can be improved. We encourage more researchers to undertake this work utilizing regional, systems, and interdisciplinary approaches. Research at a regional level can offer a range of benefit to researchers, policymakers, and natural resource managers, and needs much more attention (Ericksen, Ingram, \& Liverman, 2009). Furthermore, in order to assess sustained and equitable access to food security, appropriate research approaches need to be capable of capturing the interlinked relationships that compose the food system (Ericksen et al., 2009). One good example of this is supply-chain studies that do not require extensive resources, but are enhanced by the participation of researchers from relevant disciplines.

Inter- and/or transdisciplinary research is an important way to understand the complexity, contradictions, and the complementarities of food systems, but there are few integrated examples in 
the U.S. (see Institute of Medicine \& National Research Council, 2015). We have started to operationalize this integration in EFSNE and believe that we have helped lay the groundwork for a better understanding of food systems in general, and the Northeast food system in particular. We urge scholars and practitioners to take a broader and deeper view of their regions through a systems lens in order to advance thinking and action related to scale, supply chains, biodiversity, resiliency, and other elements critical to long-term food security.

\section{Acknowledgements}

We very much appreciate the contributions that Kristen Devlin and Raychel Santo made to this manuscript.

\section{References}

Agriculture and Agri-Food Canada. (2012). American eating trends report: Bread. Retrieved from http://www.agr.gc.ca/resources/prod/Internet-Internet/MISB-DGSIM/ATS-SEA/PDF/6257-eng.pdf

Alkhannan, F. M. M., Lee, J., Gómez, M. I., \& Gao, H. (2017). A systems approach to carbon policy for fruit supply chains: Carbon-tax, innovation in storage technologies or land-sparing? (Working Paper No. 2017-04). Retrieved from https://dyson.cornell.edu/faculty-research/working-papers/documents/WP-17-04.pdf

Atallah, S. S., Gómez, M. I., \& Björkman, T. (2014). Localization effects for a fresh vegetable product supply chain: Broccoli in the eastern United States. Food Policy, 49(1), 151-159. https://doi.org/10.1016/i.foodpol.2014.07.005

Cleary, R., Bonanno, A., \& Cho, C. (2017). Describing U.S. households' food purchasing patterns across poverty and urban status: The EFSNE project market basket. Retrieved from http://aese.psu.edu/nercrd/publications/rdp/describing-UShouseholds-food-purchasing-patterns-efsne-market-basket

Ericksen, P. J., Ingram, J. S. I., \& Liverman, D. M. (2009). Food security and global environmental change: Emerging challenges. Environmental Science \& Policy, 12(4), 373-377. https://doi.org/10.1016/i.envsci.2009.04.007

Griffin, T., Conrad, Z., Peters, C., Ridberg, R., \& Tyler, E. P. (2014). Regional self-reliance of the Northeast food system. Renewable Agriculture and Food Systems, 30(4), 349-363. https://doi.org/10.1017/S1742170514000027

Institute of Medicine \& National Research Council. (2015). A framework for assessing effects of the food system. Washington, D.C.: The National Academies Press. http://dx.doi.org/10.17226/18846

Jones, J. W., Antle, J. M., Basso, B., Boote, K. J., Conant, R. T., Foster, I.,... Wheeler, T. R. (2017). Brief history of agricultural systems modeling. Agricultural Systems, 155, 240-254. https://doi.org/10.1016/j.agsy.2016.05.014

King, R. P., Hand, M. S., DiGiacomo, G., Clancy, K., Gómez, M. I., Hardesty, S. D., ... McLaughlin, E. W. (2010). Comparing the structure, size, and performance of local and mainstream food supply chains (Economic Research Report No. 99). Retrieved from https://www.ers.usda.gov/publications/pub-details/?pubid=46407

Lowe, M., \& Gereffi, G. (2009). A value chain analysis of the U.S. beef and dairy industries. Retrieved from http://www.oecommunity.com/sites/default/files/Value $\% 20$ Chain $\% 20$ Beef $\% 20 \% 26 \% 20$ Dairy.pdf

McKinnon, R. A., Reedy, J., Morrissette, M. A., Lytle, L. A., \& Yaroch, A. L. (2009). Measures of the food environment: A compilation of the literature, 1990-2007. American Journal of Preventive Medicine, 36(4, Supplement), S124-S133. https://dx.doi.org/10.1016/j.amepre.2009.01.012

Muth, M. K., Sweitzer, M., Brown, D., Capogrossi, K., Karns, S., Levin, D.,...Zhen, C. (2016). Understanding IRI household-based and store-based scanner data. Retrieved from https://econpapers.repec.org/RePEc:ags:uerstb:234905

Mutiibwa, D., Fleisher, D., Resop, J., \& Timlin, D. (2017). Regional food production and the potential of land redistribution adaptation to climate change in the US Northeast seaboard. Manuscript in preparation.

Nicholson, C. F., He, X., Gómez, M. I., Gao, H. O., \& Hill, E. (2015). Environmental and economic impacts of localizing food systems: The case of dairy supply chains in the northeastern United States. Environmental Science \& Technology, 49(20), 12005-12014. https://doi.org/10.1021/acs.est.5b02892

Northern Grain Growers Association. (n.d.). Vermont grains history. Retrieved April 10, 2017, from http://northerngraingrowers.org/vermont-grains-history

Park, K., Gómez, M., \& Clancy, K. (2017). Case studies of supermarkets and food supply chains in low income areas of the Northeast. Report in preparation. 
Peters, C., Clancy, K., Hinrichs, C., \& Goetz, S. (2017). Introduction to the EFSNE project collection of papers. Journal of Agriculture, Food Systems, and Community Development, 7(4), 159-162. https://doi.org/10.5304/jafscd.2017.074.019

Peters, C. J., Picardy, J., Darrouzet-Nardi, A. F., Wilkins, J. L., Griffin, T. S., \& Fick, G. W. (2016). Carrying capacity of U.S. agricultural land: Ten diet scenarios. Elementa: Science of the Anthropocene, 4. https://doi.org/10.12952/journal.elementa.000116

Podhaizer, S. (2008, October 15). No grain, no gain [Blog post]. Retrieved from http:/ / www.sevendaysvt.com/vermont/no-grain-no-gain/Content?oid=2135384

Resop, J. P., Fleisher, D. H., Timlin, D. J., Mutiibwa, D., \& Reddy, V. R. (2016). Climate, water management, and land use: Estimating potential potato and corn production in the U.S. Northeastern Seaboard Region. Transactions of the ASABE, 59(6), 1539-1553. https://doi.org/10.13031/trans.59.11748

Ruhf, K., \& Clancy, K. (2010). It takes a region: Exploring a regional food systems approach. Retrieved from http://nesawg.org/sites/default/files/NESAWGRegionalFoodSystemFINALSept2010.pdf

Speer, N., Brink, T., \& McCully, M. (2015). Changes in the ground beef market and what it means for cattle producers. Retrieved from https://www.angusonline.org/Fdn/Files/Research/WP GroundBeefMarket.pdf

U.S. Bureau of Labor Statistics. (2014, September). Consumer Expenditure Survey 2012, Table 1101. Retrieved from https://www.bls.gov/cex/2013/combined/quintile.pdf

U.S. Department of Agriculture, Economic Research Service [USDA ERS]. (2015). Vegetables and pulses yearbook. Retrieved January 19, 2017, from http://usda.mannlib.cornell.edu/usda/ers/VEGANDPULSESYEARBOOK/2015/index.html

USDA ERS. (2016a). Fruit and tree nuts yearbook tables. Retrieved January 19, 2017, from https://www.ers.usda.gov/dataproducts/fruit-and-tree-nut-data/yearbook-tables/ - All Yearbook tables

USDA ERS. (2016b, October 28). Supply and utilization yearbook table. Retrieved from https://www.ers.usda.gov/dataproducts/fruit-and-tree-nut-data/yearbook-tables/

USDA ERS. (2017). Data by commodity - Imports and exports. Retrieved February 10, 2017, from https://data.ers.usda.gov/reports.aspx?programArea $=$ veg\&groupName $=$ Vegetables\&commodityName $=$ Potatoes\& $\underline{\mathrm{ID}}=17858$

USDA National Agricultural Statistics Service [USDA NASS]. (2016a). Crop production, 2015 summary. Retrieved from https://www.usda.gov/nass/PUBS/TODAYRPT/cropan16.pdf

USDA NASS. (2016b). Vegetables, 2015 summary. Retrieved from http://usda.mannlib.cornell.edu/usda/nass/VegeSumm//2010s/2016/VegeSumm-02-04-2016.pdf

USDA NASS. (2016c). Livestock slaughter, 2015 summary. Retrieved from http://usda.mannlib.cornell.edu/usda/nass/LiveSlauSu/2010s/2016/LiveSlauSu-04-20-2016.pdf

USDA NASS. (2016d). Milk production, disposition, and income, 2015 summary. Retrieved from http://usda.mannlib.cornell.edu/usda/nass/MilkProdDi//2010s/2016/MilkProdDi-04-28-2016.pdf

USDA NASS. (2016e). Non-citrus fruits and nuts, 2015 summary. Retrieved from http://usda.mannlib.cornell.edu/usda/nass/NoncFruiNu//2010s/2016/NoncFruiNu-07-06-2016.pdf

USDA NASS. (2016f, September). Potatoes, 2015 summary. Retrieved from http://usda.mannlib.cornell.edu/usda/nass/Pota//2010s/2016/Pota-09-15-2016.pdf

USDA NASS. (2017). Quick Stats [Online data portal]. Retrieved April 7, 2017, from https://quickstats.nass.usda.gov

Yeh, D. A., Nishi, I., \& Gómez, M. (2017). Supply chain impacts of vegetable demand growth: The case of cabbage in the U.S. (Working Paper 2017-05). Retrieved from http://publications.dyson.cornell.edu/research/researchpdf/wp/2017/Cornell-Dyson-wp1705.pdf 